\title{
Co-operative or coyote? Producers' choice between intermediary purchasers and Fairtrade and organic co-operatives in Chiapas
}

\author{
Anna Birgitte Milford \\ Norwegian Agricultural Economics Research Institute
}

\section{I mplications}

This study of organic and Fairtrade co-operatives in Mexico aims to find out why many coffee producers prefer not to join the certified co-operatives, despite their higher price offer. A study of costs of production of organic coffee concludes that it implies more work, but not necessarily higher yields. A main conclusion of the investigation is that the compulsory organic production methods deters many producers from entering the cooperatives, and that it is more attractive for producers with more free family labour, and less attractive for producers with very little coffee land. However, the study also shows that it is not only economic factors that influence the decisions of the producers on where to sell their coffee.

Previous studies have shown that Fairtrade and organic certification can bring higher incomes and more security into the lives of marginalized farmers (Bray et al. 2002, Martinez-Torres 2006, Jaffeee 2007) hence it is important to understand more about how these systems can achieve their aims. This study shows that although the smallest farmers are less likely to become a part of these systems, the farmers who do are also very poor and vulnerable. Also, co-operatives need to be economically viable organisations and the organic requirements ensure a market with a higher price for the product, while at the same time keeping the organization at a manageable size. It is therefore recommended to keep the organic production requirements as a criteria for producers entering the co-operatives.

\section{Background and objectives}

Many coffee producers in Chiapas, as well as in other parts of the coffee producing world, are in a situation where they can choose to sell their coffee to a Fairtrade and organically certified co-operative, or to a local intermediary purchaser. Knowing that the certified cooperatives receive price premiums for their coffee, it may seem like a paradox that many producers choose the private intermediary before the co-operative. One possible explanation is the requirement to produce organically, which is more time consuming and therefore makes the co-operative option less attractive. But it is also possible that personal preferences not based on economic deductions may influence the decision.

Several studies have found that organic coffee production implies more work than conventional (J affee 2007, Gliessman 2008, Gobbi 2000, Bray et al. 2002, MartinezTorres 2006, Lyngbæk et al. 2001). Other studies have also found that it generates higher yields than natural production, which is production with neither chemical inputs nor specific organic methods (Martinez-Torres 2006, Bolwig et al. 2009). Some studies have found that coffee production with chemical inputs generates higher yields than production with organic methods (Martinez-Torres 2006, Kilian et al. 2006, Lyngbæk et al. 2001). According to Martinez-Torres (2006), organic farming, which is cash-cheap and labour intensive, is appropriate for the cash-poor families in Chiapas, where underemployment is high and opportunity costs for extra family labour is low. Hence smaller farmers are more likely to be organic and larger farmers are more likely to use chemical technology (Martinez-Torres 2006). The tendency for Fairtrade and organic cooperative members to have smaller coffee areas and a higher ratio of on-farm family labour per coffee hectare was also found in a more recent study from Nicaragua (Beuchelt and Zeller 2011). On the other hand, Bray et al. (2002) finds in their study of three organic coffee co-operatives in Chiapas that the members are predominately from the 2-5 hectares stratum, and not from the smallest producers with less than 2 hectares. 


\section{Key results and discussion}

Coffee producers have a variety of reasons for not wanting to join certified co-operatives, despite their better price offer. The qualitative study from Chiapas finds that the most often mentioned reason is the requirements for organic production. This corresponds to the results of a household survey from the municipality of Jitotol, where many producers claim that they do not want to join the organic co-operative because of the extra work load. A study of work hours spent by co-operative members and non-members in the area shows that the members do spend more time in their coffee field than nonmembers. They particularly spend more time on making and applying compost, as well as renovating coffee trees. Also harvesting takes more time, since only the ripe berries are picked, and since they have to pick all the berries in order to avoid diseases from spreading. The requirements to work more, and the fixed costs in organic coffee production, indicate that membership should be more profitable for producers with more available work force in the family, and less profitable for producers with very little coffee production. This is confirmed in a probit analysis on the household data from the same area.

In order to increase the number of producers organised in Fairtrade and organic co-operatives, one could facilitate the producers' conversion to organic production methods, by information, training or financial support. But also non-economic aspects are important, such as the building up of trust in co-operative organisations in general. A lack of trust is due to corruption being too common in co-operatives, as it is in other firms and organisations in Latin America. Supervision of co-operative leaders, such as the one conducted by FLO, may thus have a long term positive effect on the attractiveness of these organisations. Another insight derived from this study is that for co-operative membership to be attractive it is important that the price offered by the cooperative remains at a higher level than that of the "coyote". A fall in the demand for labelled coffee which reduces the income of the co-operatives would make them less attractive. The work of those who promote labelled coffee is therefore of great importance.

\section{How work was carried out?}

Several methods were used for the study:

1. Qualitative study among coffee co-operatives and other stakeholders in Chiapas, Mexico. During a 10 month period interviews where recorded, transcribed and analysed with the software NVivo.

2. Survey of 38 organic co-operatives in Chiapas, asking questions about their structure, regulations and price policy. Used for summary statistics.

3. Survey of costs of production. 80 producers in Jitotol, Chiapas that were eithed organically certified, using chemicals, or neither. Used for summary statistics.

4. Household survey among 153 producers in Jitotol. Used for summary statistics and probit analysis.

\section{References}

Bolwig, S., Gibbon, P., Jones, S. 2009. The Economics of Smallholder Organic Contract Farming in Tropical Africa, World Development 37(6): 1094-1104

Bray, D. B.; Sánchez, J. L. P.; Murphy, E.C. 2002. Social Dimensions of Organic Coffee Production in Mexico: Lessons for Eco-Labeling I nitiatives, Society and Natural Resources 15: 429-446

Gliessman, S. R. 2008. Agroecological Foundations for Designing Sustainable Coffee Agroecosystems, In: Christopher M. Bacon, V. Ernesto Méndez, Stephen R. Gliessman, David Goodman and Lonathan A. Fox (eds) Confronting the Coffee Crisis : Fair Trade, Sustainable Livelihoods and Ecosystems in Mexico and Central America. MIT Press

Gobbi, J. A 2000. Is biodiversity-friendly coffee financially viable? An analysis of five different coffee production systems in western El Salvador, Ecological Economics 33, pp. 267-281

Jaffee, D. 2007. Brewing justice: fair trade coffee, sustainability, and survival. University of California Press

Kilian, B.; Jones, C.; Pratt, L., Villalobos, A. 2006. Is sustainable agriculture a viable strategy to improve farm income in Central America? A case study on coffee, Journal of Business Research 59:322-330

Lyngbæk A.E., Muschler, R.G. and Sinclair F.L. 2001. Productivity and profitability of multistrata organic versus conventional coffee farms in Costa Rica, Agroforestry Systems 53: 205-213

Martinez-Torres, M.E. 2006. Organic Coffee: Sustainable Development by Mayan Farmers. Ohio University Press 